\title{
Virus, veritas, vita
}

\section{Bernard M Y Cheung 다, Hang Long Li}

More by accident than by design, a special themed issue on infectious disease in the Postgraduate Medical Journal was planned last year but comes out in this annus horribilis overshadowed by COVID-19. Although the Postgraduate Medical Journal champions many themes of contemporary relevance and significance, including equal opportunity, ${ }^{1}$ gender equality ${ }^{2}$ and burn-out, ${ }^{3}$ it has also been receiving many manuscripts and images related to infectious disease. Therefore, this is a good moment to focus on what is preoccupying people most in the world today.

COVID-19 began in December 2019 as a mysterious cluster of atypical and life-threatening pneumonia in Wuhan, ${ }^{4}$ a modern commercial and industrial city of more than 11 million inhabitants (more than London, UK). These patients were not the typical frail and elderly patients with pneumonia, and they did not respond to antibiotics. The clinical picture resembled the atypical pneumonias caused by the SARS coronavirus 17 years ago. This time round, the virus was rapidly identified and its sequence was published in January $2020 .^{5}$ On 3 January 2020, before the Chinese government publicly acknowledged an epidemic, the US Centres for Disease Control and Prevention was informed. The WHO initially thought that the outbreak was largely limited to China and there was no need for widespread panic. The WHO Collaborating Centre for Infectious Disease Epidemiology and Control, however, announced on Chinese New Year's Day that the virus disease from Wuhan would rapidly involve cities within and outside China because of rail and air travel. ${ }^{6}$ This was only a mathematical projection, but nevertheless rang the alarm bells. There were already hundreds if not thousands of cases in Wuhan. The early epidemiology showed that the reproductive number $\left(\mathrm{R}_{0}\right)$ of the virus was around 2 , which means that on average, each infected person would infect two other persons. An $\mathrm{R}_{0}$ greater than 1 means that the epidemic can take off. To stop the epidemic, the $\mathrm{R}_{0}$ must be reduced to below 1 . This was done in China, with lockdown of cities and

Department of Medicine, University of Hong Kong, Hong Kong, Hong Kong

Correspondence to Professor Bernard M Y Cheung, Department of Medicine, University of Hong Kong, Hong Kong, University Department of Medicine, Hong Kong, Hong Kong; mycheung@hku.hk
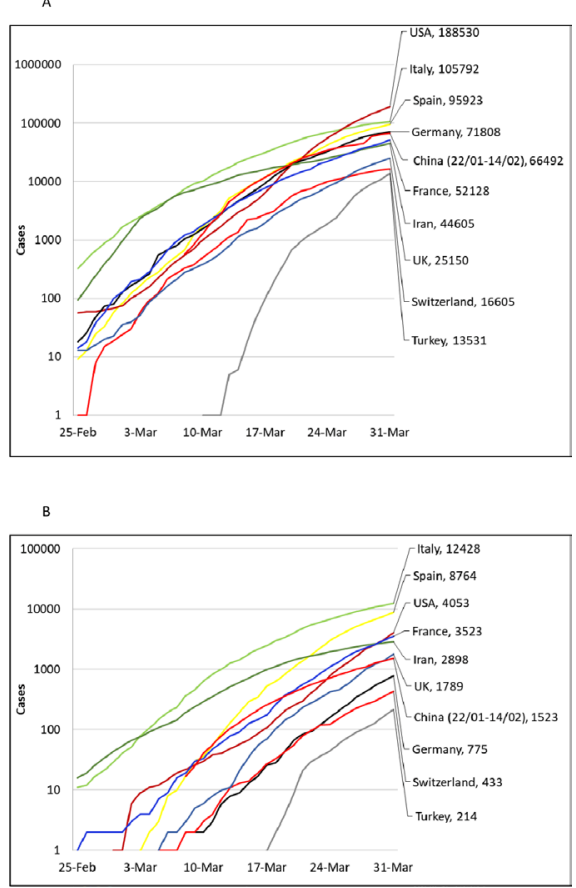

Figure 1 (A) Cumulative number of diagnosed cases. (B) Cumulative fatalities.

severe restrictions on travel, quarantine of infected and suspected cases and contacts. This ancient method of isolation started by 14th-century Venetians remains an effective way of containing the spread of the disease.

Unfortunately, before this was done, people carrying the virus, some of whom might be asymptomatic, had travelled far and wide. In a matter of weeks, there were alarming increases in the number of infected cases in South Korea, Iran and Italy, followed by other countries such as Spain, Germany, France, Switzerland, UK and USA. ${ }^{7}$ The WHO, extremely reluctant to announce a pandemic at first, finally admitted that fact on 11 March 2020. As at 31 March 2020, there were 858319 cases and 42302 fatalities. $^{\text {? }}$

There is enormous controversy surrounding the name of the virus and the infection. The correct names at present are SARS-CoV-2 and COVID-19, respectively. The WHO justifiably takes the view that new infections should not be named after places, occupations, and so on, as that could cause stigma. China, naturally, dislikes the virus being named after Wuhan. In this era of political correctness, there is a point, although in the olden days, naming leprosy and plague after Hansen and Yersin, respectively, was a mark of respect. Nevertheless, calling the disease Wuhan or Chinese coronavirus gives the misleading impression that if you are thousands of miles away, you would not catch the disease. Sadly, the origins of the virus is still unknown, because the Wuhan Seafood Market has been thoroughly sanitised. Neither the suspected animal host (a bat), nor the first infected patient, has been found.

The epidemiology of COVID-19 is terrifying. The number of affected cases has been doubling every 3 days in multiple countries (figure 1). When the number of deaths exceeds three figures, politicians' hands are forced and drastic measures have to be taken belatedly. Schools have to be closed. People have to work from home. Travel has to be banned and borders are closed. This is a historical juncture for human civilisation. If unchecked, half the world's population could be infected with corresponding numbers of the dead; case fatality rate stands at around 1\% in developed countries but can be higher in poorer countries, or when medical services are saturated.

As can be seen in figure 1 , which shows the case numbers and fatalities in the 10 countries with the most cases, the number of cases and fatalities rose exponentially irrespective of ethnicity, climate or affluence. People in business and finance understand exponential growth very well, but sadly the public, and many journalists, do not. There is astonishment at the daily 'record-breaking' number of new cases and deaths. Due to misplaced complacency, opportunities to contain the epidemic was missed during the early phase of exponential growth. A doubling time of 3 days is horrifying; imagine an inflation rate of $100 \%$ every 3 days!

Although vaccines are now being developed and will shortly be tested, they will not be available soon enough to save the world. Remdesivir, developed by Gilead for Ebola virus, is now undergoing clinical trials in Wuhan and the USA. It did not work for the Ebola virus despite much fanfare, so we can only keep our fingers crossed and pray that it might work for COVID-19. Like HIV, a single agent may not be as effective as a cocktail of agents. Kaletra, a combination of lopinavir and ritonavir, is being tested. The early results are not encouraging. ${ }^{8}$ President Trump opined that chloroquine (or hydroxychloroquine) might be useful. Using a combination of existing drugs to combat the new virus is probably the most practical strategy, but we must manage our expectations in that while treatment might shorten the duration of the illness in early or mild 
Table 1 Public health measures to reduce the transmission of COVID-19

\begin{tabular}{|c|c|}
\hline Public health measures & Examples \\
\hline Travel restrictions & $\begin{array}{l}\text { Border closure, port closure, flight cancellations, compulsory quarantine of } \\
\text { travellers }\end{array}$ \\
\hline School closures & Closure of nurseries, schools and universities \\
\hline \multicolumn{2}{|l|}{ Working from home } \\
\hline Reducing public gathering & $\begin{array}{l}\text { Closure of non-essential shops, bars, restaurants, cinemas, theatres, sports grounds, } \\
\text { gyms and places of worship }\end{array}$ \\
\hline Screening for fever & Temperature checks at entrances \\
\hline Diagnostic test & Rapid high-throughput test made widely available \\
\hline Isolation and quarantine & Isolation of close contacts and people tested positive. Quarantine of travellers \\
\hline Opening dedicated wards or hospitals & Isolation wards attended by staff with personal protective equipment \\
\hline \multicolumn{2}{|l|}{ Releasing prisoners } \\
\hline Lockdown with law enforcement & Stay at home except for essential activities, business or travel \\
\hline
\end{tabular}

disease, in advanced disease characterised by lung fibrosis and respiratory failure, the prognosis is likely to remain poor.

In hospitals, proper triage of patients to separate infected patients from vulnerable patients is important. Testing for the virus must be rapid and the throughput has to be high. Most hospitals do not have enough isolation facilities and intensive care beds to cater for an exponential rise in patients with COVID-19. The desperate situation in Lombardy is a painful lesson for all. Unfortunately, the UK and the USA are going down the same path. The governments in countries fortunate enough to have few cases at present should aim at containing the infection so that there are enough hospital beds and facilities, and importantly, hospital staff, to cope with the stream of patients. Once the number of new infections equals the number of recovered and discharged cases, the situation will stabilise.

While governments can enact policies to restrict travel and gatherings (table 1), every person in the community can do their part (table 2). Hand sanitation, not touching mucous membranes with unclean hands, wearing a mask in crowded places and good environmental hygiene are all important. In multistorey buildings, making sure that the plumbing is up to standard and keeping the lid on when flushing the toilet should be practised.

COVID-19 is putting the whole of humankind at stake. It is neither a Chinese virus, Japanese virus or Italian virus. It is 'one world, one virus'. Increasingly, it looks like 'one solution' too. Concerted actions from governments and taking personal responsibility for one's health and preventing people around you from infection should lift us out of this crisis. There is light at the end of the tunnel. The countries affected by COVID-19 earliest are showing signs of recovery. The number of cases in China has dropped dramatically. The number of new cases in South Korea and Japan has also greatly declined. The exponential rise in Italy and Iran is now less steep. In time, other countries will follow suit.

Once the pandemic is over, there will be recovery, but the world will be changed forever. People will be more health conscious and there will be public consensus for more funding on health, on building hospitals and on research. People will be more accustomed to online teaching and learning. More people will work from home, which would be a great boon to families with young children or elderly who need looking after. Unnecessary meetings will be phased out. Performers, many of whom are out

Table 2 Personal health measures to reduce the transmission of COVID-19

\begin{tabular}{|c|c|}
\hline Personal health measures & Examples \\
\hline Stay at home & Work from home, online learning \\
\hline Eat at home & Avoid bars, restaurants. Order take-away food \\
\hline Shop at home & Shop online, use online banking \\
\hline Use contactless payment & Avoid using banknotes and coins if possible \\
\hline Social distancing and avoiding gatherings & Use electronic communication. Keep at least $1 \mathrm{~m}$ away from others \\
\hline Hygiene & $\begin{array}{l}\text { Hand hygiene, not touching mucous membranes. Frequent handwashing and } \\
\text { use of alcohol rub }\end{array}$ \\
\hline Sanitation & $\begin{array}{l}\text { Disinfection of lavatories, flushing toilet with the lid on and thorough } \\
\text { handwashing }\end{array}$ \\
\hline Cleaning and disinfection & Clean and disinfect surfaces regularly and after use \\
\hline Appropriate personal protective equipment & Mask, eye shield if appropriate \\
\hline Protect other people & $\begin{array}{l}\text { Avoid contact with other people if one has fever or other symptoms. Cover } \\
\text { mouth and nose when coughing or sneezing }\end{array}$ \\
\hline
\end{tabular}

of work at the moment, will transition to presenting their performances online and recording them for posterity. While many businesses will fold, others will take their place. People now have more leisure time, because of less commuting to work, and have more time to read books, learn new things, grow their gardens and make proper meals. While I would not encourage people to find veritas in vino, I am hopeful that la vita after the COVID-19 is dolce.

Contributors $B C$ wrote the first draft. HLL analysed the data and created the graphs. Both authors critically revised the manuscript.

Funding The authors have not declared a specific grant for this research from any funding agency in the public, commercial or not-for-profit sectors.

\section{Competing interests None declared.}

\section{Patient consent for publication Not required.}

Provenance and peer review Not commissioned; internally peer reviewed.

This article is made freely available for use in accordance with BMJ's website terms and conditions for the duration of the covid-19 pandemic or until otherwise determined by BMJ. You may use, download and print the article for any lawful, non-commercial purpose (including text and data mining) provided that all copyright notices and trade marks are retained.

(C) Author(s) (or their employer(s)) 2020. No commercial re-use. See rights and permissions. Published by BMJ.

\section{Check for updates}

To cite Cheung BMY, Li HL. Postgrad Med J

2020:96:371-372.

\section{Received 2 April 2020}

Accepted 3 April 2020

Published Online First 28 April 2020

Postgrad Med J 2020;96:371-372.

doi:10.1136/postgradmedj-2020-137802

\section{ORCID iD}

Bernard M Y Cheung http://orcid.org/0000-0001-91067363

\section{REFERENCES}

1 Desai T, Ali S, Fang X, et al. Equal work for unequal pay: the gender reimbursement gap for healthcare providers in the United States. Postgrad Med J 2016;92:571-5.

2 Mathieson PW. Academic medicine should lead the way on gender equity: but it doesn't. Postgrad Med J 2017;93:717-8.

3 Cheung BMY. Virus, veritas, vita. Postgrad Med J2020;96:308-10.

4 Li Q, Guan X, Wu P, et al. Early transmission dynamics in Wuhan, China, of novel coronavirus-infected pneumonia. N Engl J Med 2020;382:1199-207.

5 Zhou P, Yang X-L, Wang X-G, et al. A pneumonia outbreak associated with a new coronavirus of probable bat origin. Nature 2020:579:270-3.

6 JT W, Leung K, Leung GM. Nowcasting and forecasting the potential domestic and international spread of the 2019-nCoV outbreak originating in Wuhan, China: a modelling study. Lancet 2020;395:689-97.

7 Worldometers. COVID-19 coronavirus pandemic. Available: https://www.worldometers.info/coronavirus/ [Accessed 1 Apr 2020].

8 Cao B, Wang Y, Wen D, et al. A trial of LopinavirRitonavir in adults hospitalized with severe Covid-19. N Engl J Med 2020 